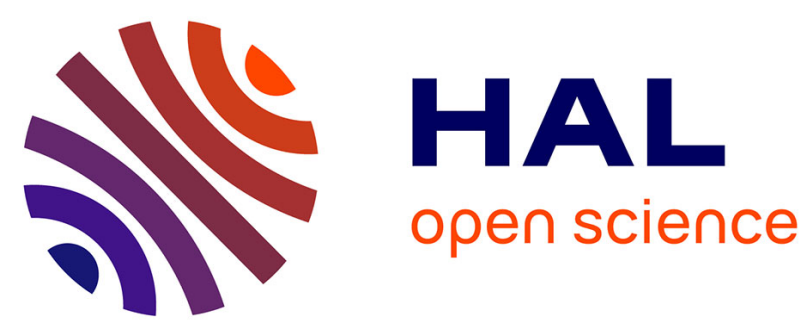

\title{
Stream ecosystems respond to riparian invasion by Japanese knotweed (Fallopia japonica)
}

Antoine Lecerf, Denise Patfield, Anatole Boiché, Miira P. Riipinen, Eric

Chauvet, Michael Dobson

\section{- To cite this version:}

Antoine Lecerf, Denise Patfield, Anatole Boiché, Miira P. Riipinen, Eric Chauvet, et al.. Stream ecosystems respond to riparian invasion by Japanese knotweed (Fallopia japonica). Canadian Journal of Fisheries and Aquatic Sciences, 2007, 64 (9), pp. 1273-1283. 10.1139/f07-092 . hal-01312783

\section{HAL Id: hal-01312783 \\ https://hal.science/hal-01312783}

Submitted on 9 May 2016

HAL is a multi-disciplinary open access archive for the deposit and dissemination of scientific research documents, whether they are published or not. The documents may come from teaching and research institutions in France or abroad, or from public or private research centers.
L'archive ouverte pluridisciplinaire HAL, est destinée au dépôt et à la diffusion de documents scientifiques de niveau recherche, publiés ou non, émanant des établissements d'enseignement et de recherche français ou étrangers, des laboratoires publics ou privés. 


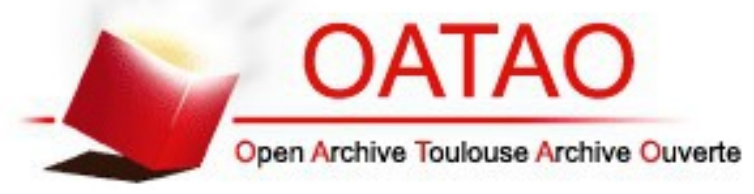

\section{Open Archive TOULOUSE Archive Ouverte (OATAO)}

OATAO is an open access repository that collects the work of Toulouse researchers and makes it freely available over the web where possible.

This is an author-deposited version published in : http://oatao.univ-toulouse.fr/ Eprints ID : 9658

To link to this article : DOI :10.1139/f07-092

URL : http://dx.doi.org/10.1139/f07-092

To cite this version : Lecerf, Antoine and Patfield, Denise and Boiché, Anatole and Riipinen, Miira P. and Chauvet, Eric and Dobson, Michael Stream ecosystems respond to riparian invasion by Japanese knotweed (Fallopia japonica). (2007) Canadian Journal of Fisheries and Aquatic Sciences, vol. 64 (n 9). pp. 1273-1283. ISSN 0706-652X

Any correspondance concerning this service should be sent to the repository administrator: staff-oatao@listes-diff.inp-toulouse.fr 


\title{
Stream ecosystems respond to riparian invasion by Japanese knotweed (Fallopia japonica)
}

\author{
Antoine Lecerf, Denise Patfield, Anatole Boiché, Miira P. Riipinen, Eric Chauvet, \\ and Michael Dobson
}

\begin{abstract}
There are growing concerns about the rapid spread of exotic plants into riparian zones, yet little information is currently available on their influence on stream ecosystems. This study assessed the impact of riparian invasion by Japanese knotweed (Fallopia japonica), an aggressive invader, on leaf litter breakdown and its associated biota (aquatic hyphomycete fungi and benthic invertebrates) in heterotrophic, low-order streams in The Pennines (England) and the Pyrenees (France). Our results suggest that leaf consumers (aquatic hyphomycetes and invertebrate shredders) can readily use knotweed leaf litter even in stream sites where it was not previously present. However, aquatic hyphomycete and invertebrate assemblages differed between stream sites with and without knotweed. Leaf litter breakdown rate and relative abundance of large invertebrate shredders (mainly Trichoptera) were enhanced in the Pyrenean invaded site, whose channel contained a high proportion of knotweed leaf litter, whereas no such effects were observed in The Pennines, possibly because of the less extensive knotweed invasion. Alteration of riparian vegetation by plant invaders could therefore increasingly influence instream community and ecological functions as the severity of invasion rises.
\end{abstract}

Résumé : En dépit des préoccupations majeures posées par la prolifération rapide de plantes exotiques dans les zones riveraines, il existe actuellement peu de données concernant les conséquences écologiques sur les cours d'eau. Dans cette étude, nous avons évalué l'effet de la renouée du Japon (Fallopia japonica), une plante éminemment envahissante, sur la décomposition des feuilles et les organismes biologiques associés (hyphomycètes aquatiques et invertébrés benthiques) dans des petits cours d'eau hétérotrophes de la région des Pennines (Angleterre) et des Pyrénées (France). Nos résultats suggèrent que les consommateurs de feuilles (hyphomycètes aquatiques et invertébrés déchiqueteurs) peuvent aisément utiliser la litière de renouée, même au sein des tronçons de cours d'eau où elle n'était pas présente auparavant. Cependant, les assemblages d'hyphomycètes aquatiques et d'invertébrés différent entre les tronçons de cours d'eau avec et sans renouée du Japon. La vitesse de décomposition des litières et l'abondance relative des invertébrés déchiqueteurs de grande taille (principalement les Trichoptères) ont augmenté au niveau du site pyrénéen envahi où domine la litière de renouée. Ces résultats ne s'observent pas sur le site envahi des Pennines, peut-être en raison de la moindre ampleur de l'invasion par la renouée. Ainsi l'impact des plantes exotiques sur la structure et les fonctions écologiques des communautés aquatiques pourrait être en rapport avec l'intensité de l'invasion.

\section{Introduction}

Riparian vegetation strongly influences rivers (Cummins et al. 1989; Wallace et al. 1997; Naiman et al. 2005), and therefore any changes to its structure and composition will have corresponding effects on organisms and ecological processes within the stream channel (e.g., Bärlocher and Graça 2002; Kennedy and Hobbie 2004; Lecerf et al. 2005). Riparian vegetation provides leaf litter as a primary energy supply to most forested low-order streams (Cummins et al. 1989;
Wallace et al. 1997). Aquatic hyphomycete fungi and benthic invertebrates rely heavily on leaf accumulations as both food and habitat (Cummins et al. 1989; Bärlocher 1992; Graça 2001). In turn, aquatic hyphomycetes and shredder invertebrates (leaf consumers) play an essential role in the breakdown of leaf litter, a key ecosystem-level process ensuring the transfer of leaf carbon and nutrients toward higher trophic levels (Bärlocher 1992; Gessner et al. 1999; Graça 2001). Besides being controlled by the activity of leaf consumers, litter breakdown rate is also regulated intrinsically

A. Lecerf, ${ }^{1,2}$ A. Boiché, ${ }^{3}$ and E. Chauvet. Laboratoire d'écologie fonctionnelle - EcoLab, Centre National de la Recherche Scientifique (CNRS), University of Toulouse 3, National Polytechnic Institute of Toulouse, 29 rue Jeanne Marvig, 31055 Toulouse CEDEX, France.

D. Patfield, M.P. Riipinen, ${ }^{4}$ and M. Dobson. ${ }^{5}$ Department of Environmental and Geographical Sciences, Manchester Metropolitan University, Chester Street, M1 5GD Manchester, United Kingdom.

${ }^{1}$ Corresponding author (e-mail: Antoine.Lecerf@ubc.ca).

${ }^{2}$ Present address: Department of Forest Sciences, The University of British Columbia, Vancouver, BC V6T 1Z4, Canada.

${ }^{3}$ Present address: Laboratoire Interations Ecotoxicologie, Biodiversité et Ecosystemes, CNRS, University of Metz, 2 avenue du Géneral Delestraint, 57070 Metz, France.

${ }^{4}$ Present address: APEM Ltd. Aquatic Scientists, Unit A17 Riverview, Vale Road, Heaton Mersey, Stockport, SK4 3GN, United Kingdom.

${ }^{5}$ Present address: Freshwater Biological Association, The Ferry Landing, Far Sawrey, Ambleside, Cumbria, LA22 0LP, United Kingdom. 
by the quality of litter, which varies greatly among plant species (Gessner and Chauvet 1994; Lecerf et al. 2007).

Japanese knotweed (Fallopia japonica (Houtt.) Dcne.; syn. Polygonum cuspidatum Sieb. \& Zucc.; syn. Reynoutria japonica Houtt.) originates from East Asia and was introduced to Europe and North America in the 1800s, mainly for ornament. Since then, this species and its congenerics (chiefly, Fallopia sachalinensis and Fallopia $\times$ bohemicum) have been among the most successful plant invaders ever known, becoming widespread in these continents and, more recently, in Oceania (Child and Wade 2000; Weston et al. 2005). Japanese knotweed is an atypical herbaceous plant, being easily distinguished by the gigantic size of its bamboo-like stems ( $>3 \mathrm{~m}$ tall) and the large, deciduous, heart-shaped leaves inserted on the stem by a short stalk (Beerling et al. 1994; Child and Wade 2000). Its rapid spread in the form of dense monospecific stands is ensured by long rhizomes (10-20 m) and a strong competitive ability (Pyšek and Prach 1993; Beerling et al. 1994; Weston et al. 2005).

The detrimental impacts of exotic plants, including Japanese knotweed, invading riparian zones are currently widely appreciated (Pyšek and Prach 1993; Planty-Tabacchi et al. 1996; Tickner et al. 2001), but little is known about their impacts upon the river itself. Animals associated with detritus breakdown could be affected by the alteration of riparian plant communities following knotweed invasion (Maerz et al. 2005). Furthermore, since knotweed produces a series of novel secondary compounds with antimicrobial properties (Beerling et al. 1994; Weston et al. 2005), fungal decomposers could also be susceptible to its invasion along streams. Additionally, litter dynamics in streams could be impaired by the high input rate of leaf litter representing a poor-quality food resource for leaf consumers (Beerling et al. 1994; Dangles et al. 2002). Lastly, it is questionable whether the native leaf consumers can adapt to knotweed leaf litter, because of a lack of coevolutionary history with exotic invaders.

The present study was designed to assess the possible consequences of Japanese knotweed invasion into riparian zones for the composition of leaf standing crop in streams and therefore the quality of food supply to aquatic consumers, the attributes of stream fungal and invertebrate assemblages, and the rate of leaf litter breakdown. For this purpose, we selected stream sites both with and without knotweed establishment in the riparian zone at two European locations. We also compared knotweed, as a nonindigenous species, with a native riparian tree (English oak, Quercus robur L.) with slow decomposing leaf litter, in terms of initial quality, breakdown rate, and colonization by aquatic hyphomycetes and invertebrates.

\section{Materials and methods}

\section{The study sites}

The experiment was carried out in The Pennines, northcentral England $\left(53^{\circ} 22^{\prime} \mathrm{N}, 1^{\circ} 49^{\prime} \mathrm{W} ; 220-230 \mathrm{~m}\right.$ above sea level (a.s.1.)) and the piedmont of the Pyrenees, southwestern France $\left(42^{\circ} 80^{\prime} \mathrm{N}, 0^{\circ} 35^{\prime} \mathrm{E} ; 535-580 \mathrm{~m}\right.$ a.s.1.). Stream sites were low-order (2-3) reaches with wooded riparian zones and were free of conspicuous anthropogenic stresses. A reference and an invaded site, each approximately $100 \mathrm{~m}$ in length, were selected at each location. The reference sites were selected for absence of Japanese knotweed establishment on the banks from the study reach to the source and for their proximity to the paired invaded sites. The site pairs consisted of two adjacent streams $(0.5 \mathrm{~km}$ apart $)$ immediately upstream their confluence in The Pennines. In the Pyrenees, we selected an upstream and downstream reach $1.5 \mathrm{~km}$ apart on a single stream, the upper limit of the knotweed invasion being separated by $0.5 \mathrm{~km}$ from the lower limit of the upstream reference site.

Japanese knotweed formed characteristic dense stands in which few other species, mainly trees and shrubs, coexisted. The invaded sites visually differed in the size and occurrence of knotweed stands in riparian zones. In The Pennines, knotweed was present as small clumps (area $<20 \mathrm{~m}^{2}$; mean width $1 \mathrm{~m}$, range $0.5-2 \mathrm{~m}$ ) appearing recurrently along most the stream. Thus, about $40 \%$ of the sampling site was bordered by knotweed stands on at least one stream bank. In the Pyrenees, knotweed overwhelmed the understorey vegetation in riparian zones, with almost contiguous stands forming a $1 \mathrm{~km}$ long strip (mean width $3 \mathrm{~m}$, range $0.5-12 \mathrm{~m}$ ) along a $1 \mathrm{~km}$ stretch of both stream banks.

\section{Site description}

Species composition and diversity of leaf inputs to streams were monitored in the autumn by collecting 10 naturally accumulated leaf packs in the experimental reaches (Lecerf et al. 2005). These were then pooled to provide approximately $5 \mathrm{~L}$ of leaf material. Leaves were washed with tap water, sorted, oven-dried at $105{ }^{\circ} \mathrm{C}$ for $48 \mathrm{~h}$, and weighed by species. Leaf species were then assigned to three categories - fast-, medium-, or slow-decomposing according to their breakdown rate in streams as determined in the literature (Webster and Benfield 1986; Gessner and Chauvet 1994; Lecerf et al. 2007) and from personal observations. Following Dangles et al. (2002), Japanese knotweed leaf litter was assigned to the slow-decomposing category. As the timing of litter fall can differ among plant species, natural leaf packs were sampled on two occasions: early (25 October in France and 17 November in UK) and late (30 November in France and 22 December in UK) autumn.

Water chemistry was monitored on the six dates when leaf packs were added and then retrieved from the streams (see below). Temperature, $\mathrm{pH}$, conductivity, and dissolved oxygen concentration were measured in the field, and filtered water samples were used to determine alkalinity and the concentration of orthophosphate, nitrate, and ammonium following colorimetric standard methods (APHA 1998).

\section{Leaf bag experiment}

Freshly fallen leaves of English oak and Japanese knotweed were collected near the study sites in each location. Oak was selected to represent the native plant species given its importance in the riparian community of the study regions and elsewhere in Europe. Oak was also chosen because its leaf litter decomposes at a similar rate to knotweed (Dangles et al. 2002), therefore avoiding sampling bias of leaf-colonizing biota due to different residence time and leaf decomposition stage in streams. The data of Gessner and Chauvet (1994) on leaf litter chemistry and breakdown rate of native plant species from the Pyrenees were included in this study for further comparison with knotweed. 
Five grams $( \pm 0.05$, with exact mass recorded) of air-dried leaves were introduced into $10 \mathrm{~mm}$ plastic mesh bags directly after the leaves had been wetted using a spray bottle to prevent breakage during handling. Twenty bags of each leaf species were introduced into each stream site in January 2004 in the Pyrenees and in January 2005 in The Pennines. The leaf bags were secured in streams by nylon lines anchored to iron bars driven into streambed sediments.

Four extra leaf bags of each species from each of the two regions were kept in the laboratory to determine the initial dry mass:ash-free dry mass (AFDM) ratio. In addition, leaf samples of both species were used to determine the content in carbon and nitrogen (CHN-analyser, NA 2100, CE Instruments), phosphorus (ascorbic acid colorimetric method after ash digestion in $\mathrm{HCl}$ as described by Flindt and Lilleb $\emptyset$ 2005), and lignin and cellulose (acid-detergent fibre procedure as described by Gessner 2005a). Samples were ground using a Culatti micro hammer mill with a $0.5 \mathrm{~mm}$ mesh prior to the analyses.

Four bags of each leaf species were collected from each stream site after 11, 24, 34, 61, and 88 days in the Pyrenees and after 7, 27, 53, 81, and 109 days in The Pennines. Leaf bags were stored individually in plastic ziplock bags and transported to the laboratory in an ice box. Leaves were washed individually to remove sediments and exogenous organic matter along with invertebrates, which were collected in a $0.5 \mathrm{~mm}$ screen sieve and then preserved in $70 \%$ ethanol until processing. Two sets of five $12 \mathrm{~mm}$ diameter discs were cut from five leaves, avoiding the central veins; one set was frozen at $-18{ }^{\circ} \mathrm{C}$ until processing for ergosterol extraction, and the other was kept fresh to induce fungal sporulation. Fungal samples were not taken from the leaf bags collected after 7 days in The Pennines because of nonavailability of laboratory equipment. The remaining leaf litter was dried at $105{ }^{\circ} \mathrm{C}$ for $48 \mathrm{~h}$ and weighed to the nearest $0.01 \mathrm{~g}$ and ground. Portions of leaf material of about $500 \mathrm{mg}$ were ashed at $550{ }^{\circ} \mathrm{C}$ for $4 \mathrm{~h}$ and weighed to determine the organic matter content. The leaf mass remaining in bags was expressed as the ratio between final and initial leaf litter AFDM.

The five fresh leaf discs were placed in $100 \mathrm{~mL}$ Erlenmeyer flasks filled with $25 \mathrm{~mL}$ filtered (Whatman glass fibre GF/F) stream water. Production of fungal asexual spores was stimulated by gentle shaking on an orbital path at $10{ }^{\circ} \mathrm{C}$ for $48 \mathrm{~h}$. Thereafter, spore suspensions were transferred into $50 \mathrm{~mL}$ polyethylene centrifuge tubes, the flask and discs were rinsed with distilled water to collect spores no longer in suspension, and the volume was adjusted to $35 \mathrm{~mL}$ with $2 \mathrm{~mL}$ of $37 \%$ formalin and distilled water as required. The discs were then oven-dried and weighed to the nearest $0.1 \mathrm{mg}$.

\section{Processing of aquatic hyphomycetes}

Spore suspensions were supplied with $1 \mathrm{~mL}$ of Triton X$100(0.01 \%$ solution $)$ and stirred gently to ensure uniform distribution of spores. Aliquots of $5 \mathrm{~mL}$ were filtered through a membrane filter ( $5 \mu \mathrm{m}$ pore size), and the spores on the filter were stained with $0.1 \%$ trypan blue in $60 \%$ lactic acid. Two hundred spores per sample were counted and identified to species under the microscope $(\times 320)$. Spore production was calculated as the number of spores released per milligram leaf litter AFDM per day.

The frozen leaf discs were used to determine ergosterol content as a measure of fungal biomass (Gessner 2005b). The extraction and quantification method is based on solidphase extraction and high-performance liquid chromatography (adapted from Gessner 2005b, with cartridges Waters Oasis HLB, $60 \mathrm{mg}, 3 \mathrm{cc}$ ). Briefly, leaf material was freezedried, weighed to the nearest $0.1 \mathrm{mg}$, and then lipids were extracted with alkaline ethanol at $80{ }^{\circ} \mathrm{C}$ for $30 \mathrm{~min}$. Fungal biomass in leaves was expressed as ergosterol mass per milligram leaf litter AFDM.

\section{Processing of invertebrates}

Invertebrates were counted and identified to the lowest practicable level, mostly genus or species for non-Diptera insects and family or order for Diptera and some non-insect taxa (see Supplemental Tables 1 and 2, available online from the NRC Data Depository $\left.{ }^{6}\right)$. Invertebrates assigned to the shredder group were dried $\left(60{ }^{\circ} \mathrm{C}, 48 \mathrm{~h}\right)$ and weighed to the nearest $0.1 \mathrm{mg}$. Shredder biomass in leaf bags was expressed per gram AFDM of leaf litter remaining.

Among shredders, we distinguished large species from small species on the basis on their maximum potential body size, anticipating different responses to Japanese knotweed invasion of these two groups (cf. Friberg 1997; Whiles and Wallace 1997). To test this hypothesis, we calculated the odds for having large shredders (as the ratio of large to small shredder abundance) at each site. Odds ratio for invaded:reference sites significantly different from 1 (according to Fisher's exact test, two-tail) indicated differences in large shredder abundance between reference and invaded sites. In the present study, the small shredder species consisted of Plecoptera, while the large shredder species consisted of the case-bearing Trichoptera, Tipula (Diptera), and Gammarus (Crustacea: Amphipoda).

\section{Statistical analyses}

The total number of leaf species found in natural accumulations in streams over the two sampling dates and the ShannonWiener diversity index, calculated from percent occurrence (by dry mass) of leaf species at each sampling date, were used as indicators of riparian vegetation diversity (Laitung and Chauvet 2005; Lecerf et al. 2005). Invertebrate taxon richness in leaf bags for each leaf species and stream site was estimated using the individual-based rarefaction method in EcoSim (Gotelli and Entsminger 2006) to correct for difference in number of individuals counted (Gotelli and Colwell 2001). This correction was not required for fungal species richness, as we identified the same number of spores on each occasion (i.e., 200 spores).

Exponential breakdown rate $k$ of English oak and Japanese knotweed in each site was calculated from the proportion of leaf litter AFDM remaining in bags $(R)$ over the time of exposure ( $t$ in days) using a nonlinear regression procedure $\left(R=R_{0} \times \mathrm{e}^{-k t}\right.$, where $R_{0}$ is the initial proportion of leaf

\footnotetext{
${ }^{6}$ Supplementary data for this article are available on the journal Web site (cjfas.nrc.ca) or may be purchased from the Depository of Unpublished Data, Document Delivery, CISTI, National Research Council Canada, Building M-55, 1200 Montreal Road, Ottawa, ON K1A 0R6, Canada. DUD 5205. For more information on obtaining material refer to cisti-icist.nrc-cnrc.gc.ca/irm/unpub_e.shtml.
} 
Table 1. Characteristics of stream sites.

\begin{tabular}{llllll}
\hline Parameters & \multicolumn{2}{l}{ The Pennines } & & \multicolumn{2}{l}{ Pyrenees } \\
\cline { 2 - 3 } \cline { 5 - 6 } & Reference & Invaded & & Reference & Invaded \\
\hline Temperature $\left({ }^{\circ} \mathrm{C}\right)$ & $6.7(2.7-8.8)$ & $7.0(2.8-9.2)$ & & $6.1(1.5-13)$ & $6.2(1.5-12.5)$ \\
$\mathrm{pH}$ & $6.1(5.2-6.6)$ & $5.9(5.1-6.5)$ & & $7.6(7.4-7.8)$ & $7.9(7.5-7.9)$ \\
Conductivity $\left(\mu \mathrm{S} \cdot \mathrm{cm}^{-1}\right)$ & $143(95-257)$ & $97(67-122)$ & & $66(62-70)$ & $80(72-90)$ \\
Alkalinity $\left(\mathrm{mequiv} \cdot \mathrm{L}^{-1}\right)$ & $0.07(0.05-0.09)$ & $0.06(0.04-0.08)$ & & $0.75(0.72-0.81)$ & $1.05(1.03-1.92)$ \\
$\mathrm{O}_{2}\left(\mathrm{mg} \cdot \mathrm{L}^{-1}\right)$ & $11.7(10.1-13.5)$ & $11.3(9.8-12.6)$ & & $10.4(9.9-10.8)$ & $10.8(10.5-11.1)$ \\
Phosphate $\left(\mu \mathrm{g} \mathrm{P} \cdot \mathrm{L}^{-1}\right)$ & $<1^{*}$ & $<1^{*}$ & & $9.6(3.1-17.7)$ & $11.1(7.4-15.1)$ \\
Nitrate $\left(\mu \mathrm{g} \mathrm{N} \cdot \mathrm{L}^{-1}\right)$ & $590(447-644)$ & $772(628-858)$ & & $970(760-1150)$ & $1020(690-1480)$ \\
\hline
\end{tabular}

Note: Mean value (minimum-maximum) of water parameters determined during the leaf bag exposure ( $n=6$ sampling dates). *Undetectable concentration.

litter AFDM in bags). The best estimates of $k$ were reached when $R_{0}$ was not fixed a priori; however, $95 \%$ confidence interval indicated that calculated values of $R_{0}$ did not significantly differ from the theoretical value of 1 .

Results from The Pennines and the Pyrenees were analysed separately because of differences in experimental design (i.e., sampling dates). Two-way multivariate analysis of variance (MANOVA) was used to test for differences in water chemistry across sampling dates and between reference and invaded sites. Leaf litter breakdown rates among combination treatments were compared using analysis of covariance (ANCOVA), with ln-transformed $R$ as the response variable, time of exposure as the covariate, and site type and leaf species as categorical factors; both covariate and categorical factors were fully crossed following the general linear model procedure. Similarly, we used a general linear model to test for differences in fungal spore production, fungal biomass, invertebrate abundance, and shredder biomass in bags among sampling dates, site types, and leaf species. We used analysis of variance (ANOVA) with time as a categorical factor when response variables did not follow a linear trend with time. Otherwise, time was used as covariate in ANCOVA. STATISTICA 6.0 was used to perform these analyses (StatSoft 2001).

Differences in bag-associated assemblages of aquatic hyphomycetes and invertebrates between leaf species and site types in each location were assessed using canonical analyses of principal coordinates (CAP), a flexible and robust eigenvalue-based method consisting of a metric multidimensional scaling followed by a canonical discriminant analysis (Anderson and Willis 2003; Nikolcheva and Bärlocher 2005). Compared with traditional constrained ordination methods (e.g., canonical correspondance analysis), CAP has the advantage that the most appropriate distance or dissimilarity measures can be chosen. Here we used the Hellinger distance, which is sensitive to unimodal patterns of taxon abundance across ecological gradients and give reasonable weight to rare taxa (Legendre and Gallagher 2001). CAP ordination was performed using the original application program written by M.J. Anderson (2004).

When CAP indicated significant differences in aquatic hyphomycetes and invertebrates between leaf species and site types, we then looked for the taxa responsible for multivariate patterns at each location using the IndVal method (Dufrêne and Legendre 1997). Accordingly, the indicator value of the taxon $i$ in the sample of group $j$, or $\operatorname{IndVal}_{i j}$ (in
$\%)$, was defined as the product of a measure of specificity (formally, $n_{i j} / n_{i}$. where $n$ is the number of individuals) by a measure of fidelity (formally, $N_{i j} / N_{i \bullet}$, where $N$ is the number of samples containing the taxon $i$ ). The significance of the taxon-to-group associations was tested by two resampling methods and was considered when the two tests give $p<0.05$ (250 permutations; Dufrêne and Legendre 1997). In our study, the IndVal index was used to measure the strength of nonhierarchical association of aquatic hyphomycetes species and invertebrate taxa to site type (reference vs. invaded) or leaf species (oak vs. knotweed). Computation of the Ind Val index and of the randomization testing procedure was performed using the program written by M. Dufrêne (biodiversite.wallonie.be/dgrne/sibw/outils/indval/ home.html).

\section{Results}

\section{Water characteristics}

Streams were slightly acid (The Pennines) or circumneutral (Pyrenees) and displayed elevated nitrate concentrations in water $\left(>500 \mu \mathrm{g} \mathrm{N} \cdot \mathrm{L}^{-1}\right)$. Phosphate concentrations were higher in the Pyrenean stream than in the Pennine streams. Water chemistry varied across time in both locations (two-way MANOVAs: Wilks' $\lambda<0.00001, p<0.01$ ). It differed significantly between the reference and the invaded site in the Pyrenees (Wilks' $\lambda=0.0002, p=0.020$ ) but not in The Pennines (Wilks' $\lambda=0.016, p=0.213$ ). Notably, alkalinity was slightly higher in the invaded site in the Pyrenees (Table 1).

\section{Leaf standing crop}

All study sites supported a high diversity of leaves, with the species number ranging from 14 to 21 and the ShannonWiener index from 1.7 to 2.4 . In early autumn, there were large amounts of fast-decomposing leaves in all streams, but more slowly decomposing species dominated at the later sampling date (Figs. 1a, 1b). In the Pyrenees, slowdecomposing leaves were quite rare at the reference site, whereas they were abundant in the invaded site, partly owing to the presence of Japanese knotweed leaf litter (Figs. 1a, $1 b$ ). Knotweed contributed $<10 \%$ dry mass of leaf standing crop in The Pennines, whereas it represented approximately $30 \%-50 \%$ of leaf standing crop in the Pyrenees. In the latter location, native hazel (common hazel, Corylus avellana L.), which produces medium-decomposing leaves, contributed up 
Fig. 1. Composition of leaf standing crop in the Pennine and the Pyrenean streams (Ref, reference stream; Inv, invaded stream) during early $(a)$ and late autumn $(b)$. The bars represent the relative amount (by dry mass) of each leaf decomposition category (solid bars, slow; grey bars, medium; open bars, fast). Japanese knotweed (Fallopia japonica) (hatched bars) is classified as slow-decomposing.

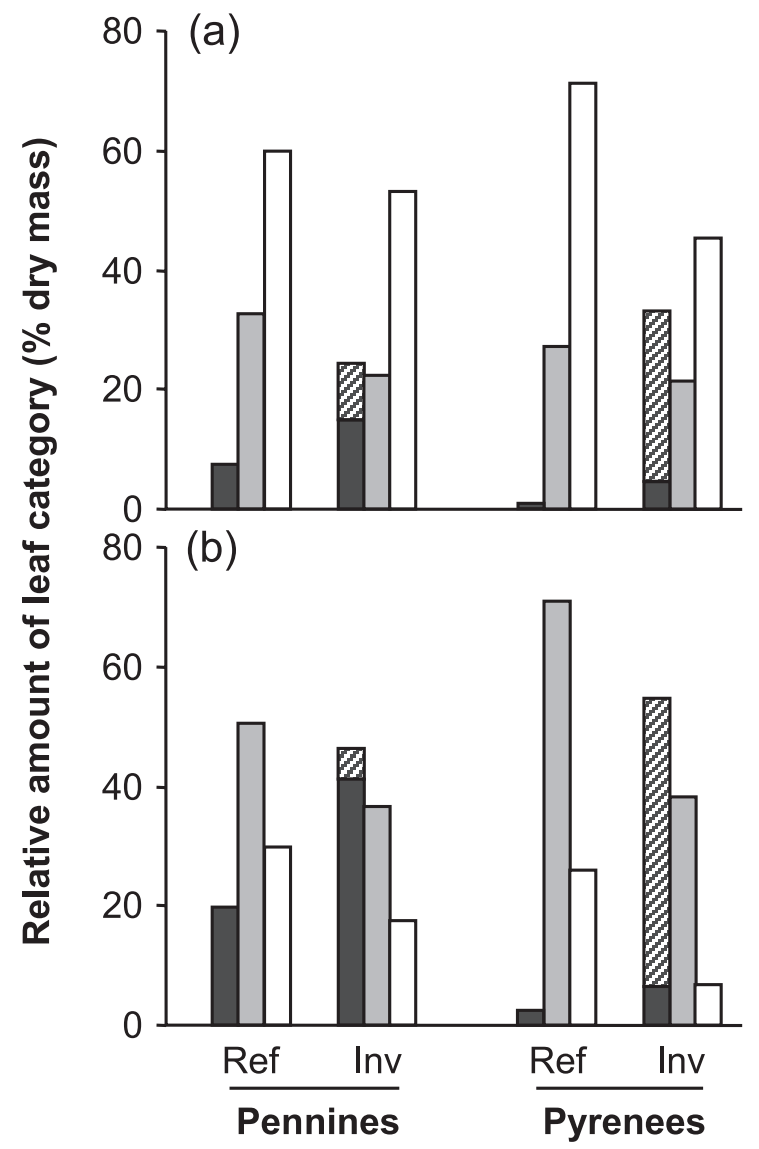

to $64 \%$ of leaf standing crop in the reference site but $<20 \%$ in the invaded site.

\section{Leaf litter quality and breakdown rate}

English oak and Japanese knotweed leaf litter used in this study differed in chemistry, with carbon and lignin content being higher in oak than in knotweed (Table 2). In addition, knotweed leaf litter had higher nitrogen and phosphorus contents than oak in The Pennines, but not in the Pyrenees (Table 2). Oak leaf litter contained more lignin and phosphorus in The Pennines than in the Pyrenees (Table 2). Overall, oak and knotweed leaf litter breakdown rates were comparable in The Pennines (ANCOVA: $F=1.1, p=0.152$ ), while knotweed disappeared slightly more rapidly than oak in the Pyrenees (ANCOVA: $F=5.7, p=0.019$; Fig. $2 a$ ). Within a broad spectrum of leaf litter quality and decomposability, breakdown rates of leaves, including knotweed, and lignin content were well fitted to a power relationship (Fig. 2b).

Irrespective of leaf species used in bags, leaf litter breakdown rates were almost the same in the reference and invaded sites in The Pennines (ANCOVA: $F=0.1, p=0.747$ ), whereas they were significantly higher in the invaded site than in the reference site in the Pyrenees (ANCOVA: $F=21.5, p<$
Table 2. Initial chemistry of Japanese knotweed (Fallopia japonica) and English oak (Quercus robur) leaf litter used in mesh bags.

\begin{tabular}{lccccc}
\hline Constituents & \multicolumn{2}{l}{ The Pennines } & & Pyrenees & \\
\cline { 2 - 3 } \cline { 6 - 6 } & Oak & Knotweed & & Oak & Knotweed \\
\hline Carbon & $53.9 \mathrm{~b}$ & $47.4 \mathrm{a}$ & & $53.8 \mathrm{~b}$ & $47.6 \mathrm{a}$ \\
Lignin & $20.8 \mathrm{c}$ & $13.7 \mathrm{a}$ & & $17.8 \mathrm{~b}$ & $13.4 \mathrm{a}$ \\
Cellulose & $11.2 \mathrm{a}$ & $12.8 \mathrm{a}$ & & $12.0 \mathrm{a}$ & $13.1 \mathrm{a}$ \\
Nitrogen & $0.97 \mathrm{a}$ & $1.82 \mathrm{~b}$ & & $0.92 \mathrm{a}$ & $0.99 \mathrm{a}$ \\
Phosphorus & $0.055 \mathrm{~b}$ & $0.119 \mathrm{c}$ & & $0.042 \mathrm{a}$ & $0.044 \mathrm{a}$ \\
\hline
\end{tabular}

Note: Identical letter indicates no significant difference (one-way analysis of variance followed by Tukey's post hoc test: $p>0.05$ ). Mean value ( $n=4$ replicates) of initial concentration of leaf litter constituents (by percent dry mass) were determined for oak and knotweed within each location.

Fig. 2. (a) Breakdown rate ( $k$ ) of English oak (Quercus robur) and Japanese knotweed (Fallopia japonica) (= Knot) leaf litter determined in a reference (open bars) and an invaded (shaded bars) stream site in The Pennines and the Pyrenees. $(b)$ Leaf litter breakdown rate as a function of lignin concentration. Values for oak (open circles) and knotweed (shaded triangles) are, respectively, from the reference and the invaded sites of this study, whereas other data (open squares) are from Gessner and Chauvet (1994).

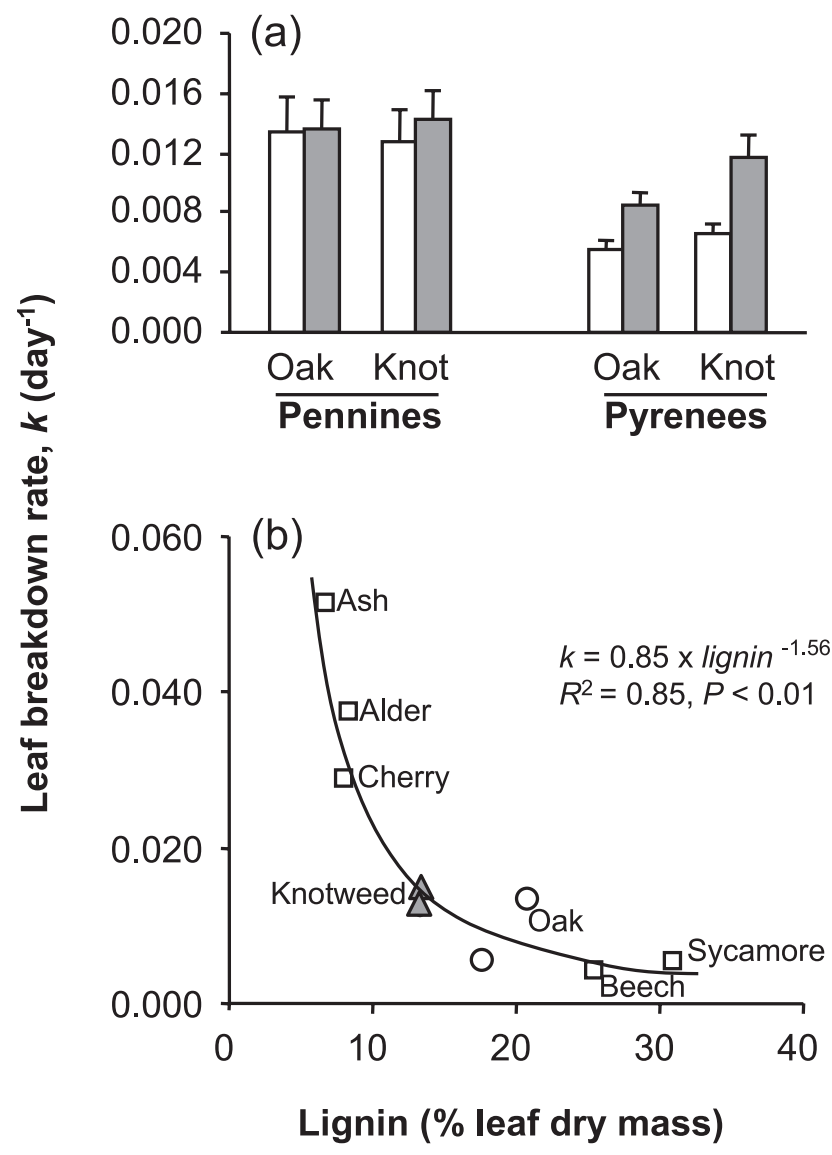

0.001; Fig. 2a). Overall, leaf litter disappeared faster in the Pennine streams than in the Pyrenean stream (Fig. 2a).

\section{Aquatic hyphomycete assemblages}

Spore production of aquatic hyphomycetes varied according to time in both locations (three-way factorial ANOVAs: 
Fig. 3. Spore production $(a, b)$ and biomass as determined by ergosterol content $(c, d)$ of aquatic hyphomycetes on English oak (Quercus robur) (circles) and Japanese knotweed (Fallopia japonica) (triangles) leaf litter in a reference (open symbols) and an invaded (shaded symbols) stream site in The Pennines $(a, c)$ and the Pyrenees $(b, d)$. Mean and 1 standard error are represented.
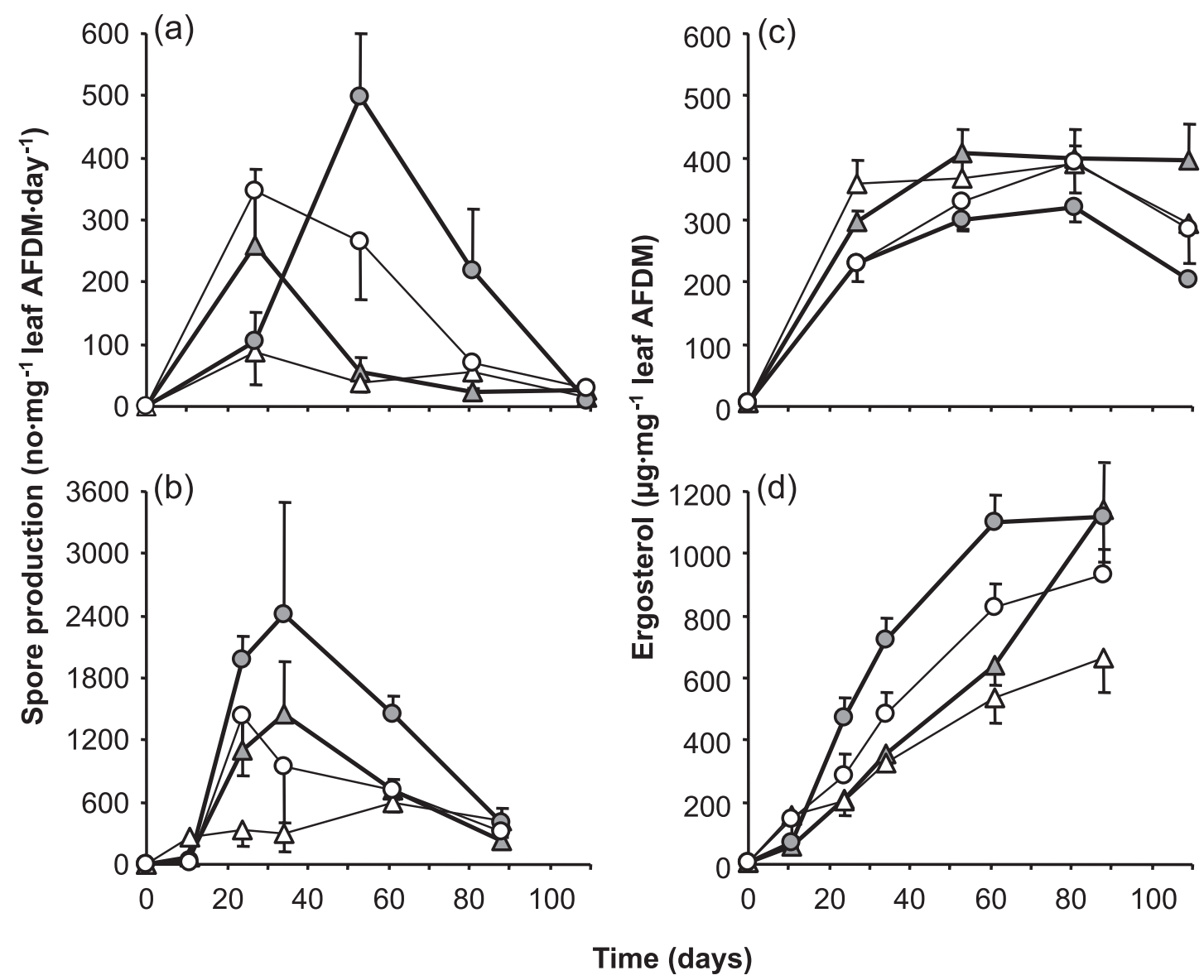

$p<0.01$; Figs. $3 a, 3 b)$. There was a significant difference between leaf species at all times in The Pennines ( $p=0.015$; Fig. $3 a$ ) and at certain times in the Pyrenees (leaf speciesby-time interaction: $p<0.001$; Fig. $3 b$ ). Spore production of aquatic hyphomycetes reached higher values on English oak than on Japanese knotweed (Figs. $3 a, 3 b$ ). Spore production on a given leaf species was also higher in the invaded site than in the reference site in both locations (Figs. $3 a, 3 b$ ), although the difference was significant in the Pyrenees only $(p=0.005)$. The interactions between leaf species and site type and among time, leaf species, and site type were not significant in either location $(p>0.12)$, yet a peak of spore production was observed in all cases except for knotweed in the reference sites (Figs. 3a, 3b). There was about a sixfold higher spore production in the Pyrenean stream than in the Pennine streams.

Fungal biomass on leaf litter as determined by ergosterol content increased with time (three-way factorial ANOVAs: $p<0.001)$, and it differed between leaf species $(p<0.001)$, with higher fungal biomass on Japanese knotweed in The Pennines and on English oak in the Pyrenees (Figs. 3c, 3d). No significant difference between site types was observed in The Pennines (site type only or in interaction with any factors: $p>0.14$ ), while higher biomass on leaf litter was found in the Pyrenean invaded site from 20 days (ANOVA, site type-by-time interaction: $p=0.001$; Fig. $3 d$ ). Fungal biomass was approximately more than two times higher in the Pyrenees than in The Pennines.

There were more fungal species on Japanese knotweed than on English oak in three of the four sites (Table 3). Irrespective of the leaf species colonized, rare species (relative abundance $<0.1 \%$ ) were more numerous in the invaded site than in the reference site in the Pyrenees (Table 3). Fungal assemblages on leaves were more diverse in the Pyrenees than in The Pennines, with rare species contributing strongly to this difference (Table 3 ). Whatever the location, assemblages of aquatic hyphomycetes differed among combination treatments (CAP canonical permutation tests, 9999 permutations: $p<0.01)$. The first factorial plane of the CAP analyses separated the reference from the invaded site and, within each site type, oak from knotweed leaves (Figs. 4a, 4c). Consistent with CAP results, the IndVal method indicated significant associations (randomization tests, 250 permutations: $p<0.05$ ) of some fungal species with either reference or invaded site or with either oak or knotweed leaf litter (see Appendix A for details). There were more significant associations in the Pyrenees than in The Pennines, and in both locations most associations were with oak; however, two and four taxa were significantly associated with knotweed in The Pennines and the Pyrenees, respectively. 
Table 3. Numbers of aquatic hyphomycete species and invertebrate taxa found in mesh bags of each leaf species (Japanese knotweed (Fallopia japonica) and English oak (Quercus robur)) exposed in each stream type in The Pennines and the Pyrenees.

\begin{tabular}{llllll}
\hline & \multicolumn{2}{l}{ Reference } & & \multicolumn{2}{l}{ Invaded } \\
\cline { 2 - 3 } $\begin{array}{l}\text { Hyphomycetes } \\
\text { The Pennines }\end{array}$ & $19(2)$ & $18(2)$ & & $16(2)$ & $18(1)$ \\
Pyrenees & $30(9)$ & $35(13)$ & & $32(13)$ & $33(17)$ \\
Invertebrates & & & & \\
The Pennines & 25 & 21 & 22 & 20 \\
Pyrenees & 27 & 22 & 25 & 27 \\
\hline
\end{tabular}

Note: The number of rare fungal species (relative abundance $<0.1 \%$ ) is given in parentheses. Individual-based rarefaction curves were used to determine taxonomic richness of invertebrates in virtual samples of 300 and 600 individuals in The Pennines and the Pyrenees, respectively.

\section{Invertebrate assemblages}

Abundance of invertebrates in leaf bags in the Pyrenees changed with time (three-way factorial ANOVA: $p<0.001$ ) and was slightly lower in the invaded site $(p=0.075$; data not shown). Variability in invertebrate abundance remained mostly unexplained in The Pennines (all effects: $p>0.10$ ). Higher abundance was found in the Pyrenees (mean value = 44.7 individuals $\cdot \mathrm{bag}^{-1}$ ) than in The Pennines (25.8 individuals $\left.\cdot \mathrm{bag}^{-1}\right)$. Biomass of shredder invertebrates increased linearly with time from origin (Figs. $5 a, 5 b$ ). Hence, we compared individual line slopes by using an ANCOVA model without comparing intercepts. In The Pennines, change in shredder biomass occurred more rapidly in English oak leaf bags than in Japanese knotweed leaf bags $(F=$ 23.9, $p<0.001$; Fig. 5a), whereas no such difference was observed in the Pyrenees $(F=0.17, p=0.68)$. Irrespective of the leaf species colonized, there was a steeper increase in shredder biomass in the invaded site than in the reference site in the Pyrenees $(F=5.8, p=0.028)$, the difference being significantly more pronounced in oak leaf bags (threeway interaction: $F=11.2, p=0.004$; Fig. $5 b$ ). In contrast, there was no significant effect of site type on shredder biomass in The Pennines $(p>0.60)$.

Whatever the location, rarefied taxonomic richness of invertebrates in the reference sites was higher in English oak leaf bags than in Japanese knotweed leaf bags, while this effect was not consistent in the invaded sites (Table 3). Oak supported a more diverse invertebrate assemblage in the reference sites than in the invaded sites. In the Pyrenees, rarefied richness of invertebrates in knotweed leaf bags was higher in the invaded site than in the reference site (Table 3). Whatever the location, assemblages of invertebrates differed among site type-per-leaf species combination treatments (CAP canonical permutation tests, 9999 permutations: $p<0.01$ ). However, this was mainly due to differences in invertebrate assemblages between site types (Figs. $4 b, 4 d$ ), and the effect of leaf species per se tested by an additional CAP was not significant at either location $(p=0.10$ and $p=0.93$ in The Pennines and the Pyrenees, respectively). Consistent with the CAP results, the IndVal method indicated that there were significant associations (randomization tests, 250 permutations: $p<0.05$ ) of some invertebrate taxa to either reference or invaded site (see Appendix A for details). In both locations, Chironomidae and Simuliidae were most closely associated with the reference sites. Among the taxa associated with the invaded sites were shredder invertebrates, two small-body-sized species in The Pennines (Plecoptera: Brachyptera risi (Taeniopterygiidae) and Amphinemura sulcicollis (Nemouridae)) and two large-bodysized species in the Pyrenees (Trichoptera: Potamophylax latipennis (Limnephilidae) and Sericostoma personatum (Serocostomatidae)).

Odds for having large shredders in leaf bags were similar at the two reference sites $(0.080$ and 0.074 in The Pennines and the Pyrenees, respectively), but odds for invaded sites differed between regions ( 0.047 and 0.256 in The Pennines and the Pyrenees, respectively). Moreover, there was a significantly higher occurrence of large shredders in the invaded site than in the reference site in the Pyrenees (odds ratio $=3.34, p<0.001$, whereas no such difference was observed in The Pennines (odds ratio $=0.59, p=0.0653$ ).

\section{Discussion}

Japanese knotweed leaf litter disappears at a rate comparable with that of common native riparian shrubs or trees that produce slow-decomposing leaf litter (e.g., oak and beech), which is consistent with the quantity of lignin in its leaf tissues (Gessner and Chauvet 1994). The absence of a marked difference in breakdown rate between knotweed and native, slow-decomposing leaf litter stresses the ability of resident aquatic leaf consumers to readily use exotic detritus sources (Graça et al. 2001). Coevolutionary history between riparian plants and aquatic biota is not required to ensure effective trophic dynamics in streams (Thompson and Townsend 2003). This idea is also supported by the absence of leaf substrate specificity of aquatic hyphomycetes in previous studies (Laitung and Chauvet 2005; Nikolcheva and Bärlocher 2005) and by the worldwide distribution of numerous dominant fungal species, but not of the vascular plant species they consume (Bärlocher 1992). Aquatic hyphomycete species may, however, differ in their ability to grow on a given leaf species, resulting in difference in spore production and structure (i.e., species relative abundance) of leaf-associated fungal assemblages between substrate types as observed in the present and previous studies (Gulis 2001; Graça et al. 2002). Similarly, some investigators have found that invertebrates may be sensitive to some traits of the leaf litter they colonize (Richardson et al. 2004; LeRoy et al. 2006), but the similar invertebrate assemblages in oak and knotweed leaf bags in this study suggest no such effect.

Consequences of Japanese knotweed invasion on stream food webs cannot be fully evaluated from observing its short-term exploitation by aquatic biota in comparison with native leaf litter. Indeed, the structure and dynamics of food webs involve a long-term adjustment process of the ecosystem to postinvasion conditions (Belnap et al. 2005; Hoffmeister et al. 2005). Thus, the occurrence of a peak of fungal spore production on knotweed in the invaded sites but not in the references sites may be due to the selection for the fungal species best adapted to growth on knotweed leaf litter. This is consistent with the idea that riparian vegetation is 
Fig. 4. First factorial plane of canonical analyses of principal coordinates on aquatic hyphomycete $(a, c)$ and invertebrate $(b, d)$ assemblages in English oak (Quercus robur) (circles) and Japanese knotweed (Fallopia japonica) (triangles) leaf bags exposed in a reference (open symbols) and an invaded (shaded symbols) stream site in The Pennines $(a, b)$ and the Pyrenees $(c, d)$.
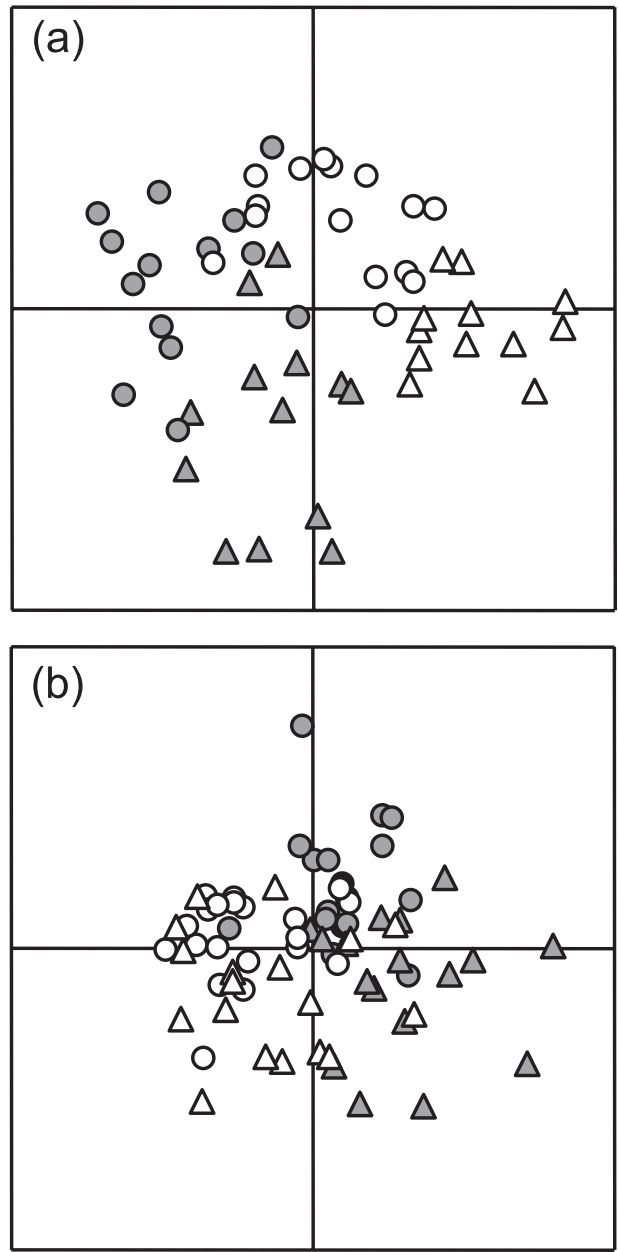

a major factor structuring aquatic hyphomycete assemblages at the stream level (Bärlocher and Graça 2002; Laitung and Chauvet 2005; Ferreira et al. 2006). Similarly, changed shredder assemblages caused by knotweed may partly be the result of selection for the taxa that are most efficient at exploiting a low-quality resource (Cummins et al. 1989; Stout et al. 1993).

In the Pyrenean invaded site, we suspect that change in composition of leaf litter inputs since Japanese knotweed establishment has benefited large shredder species, which in turn has accelerated the breakdown rate of the slowdecomposing leaves (Dangles et al. 2002; Jonsson et al. 2002). A similar causal cascade linking riparian vegetation type, large trichopteran shredders, and litter breakdown emerged from a study on a pine plantation that also produced a low quality leaf litter (Whiles and Wallace 1997). The large size and powerful mouthparts of large trichopteran shredders ensure they can consume sufficient quantities of low-quality litter to meet their nutritional requirements (Friberg and Jacobson 1999; Jonsson et al. 2002). Moreover, large shredders with long life cycles may benefit from slowdecomposing leaves, which remain abundant in streams until they complete their entire development (Cummins et al. 1989; Friberg 1997; Eggert and Wallace 2003). The dependence of large shredders on slow-decomposing leaves may
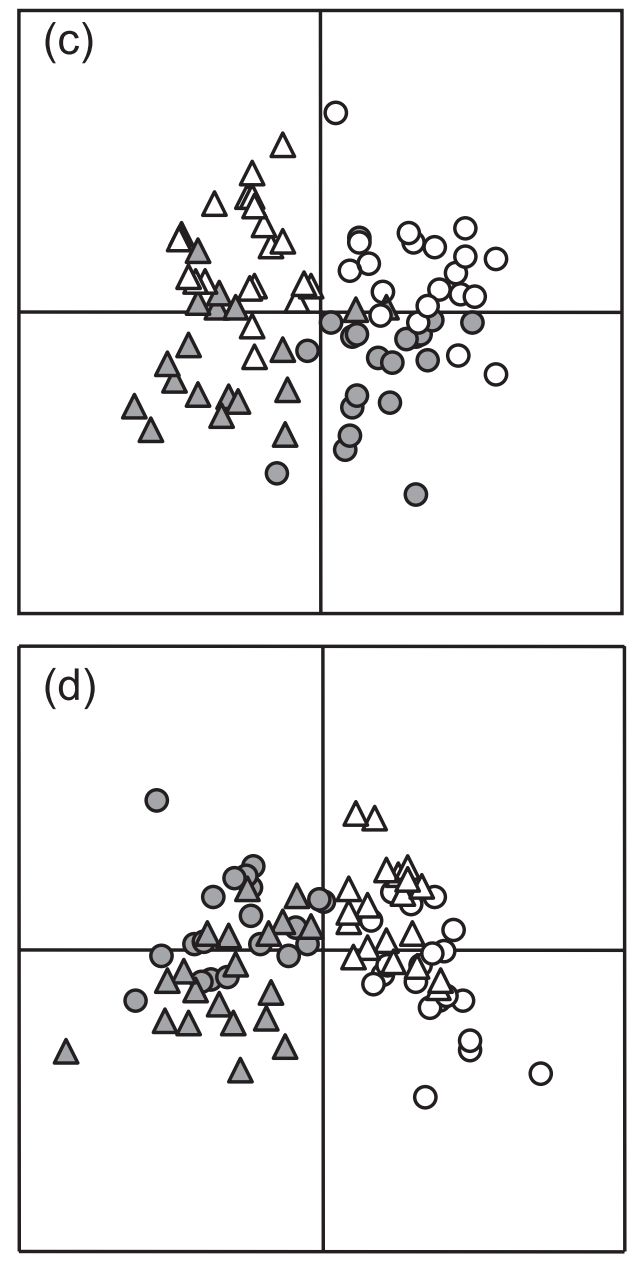

also be explained by a certain degree of trophic specialization, making the late stages of some trichopteran species less prone to use alternative high quality resources, such as benthic algae and moss, than smaller shredders, such as some plecopterans (Dangles 2002).

The fact that leaf litter breakdown rate and odds for having large shredders in leaf bags did not vary across stream sites in The Pennines shows that Japanese knotweed invasion into riparian zones can have variable effects on stream ecosystems. An analogous discrepancy has been reported from the extensive literature dealing with effects of Eucalyptus plantations on litter breakdown and invertebrate assemblages in the Iberian Peninsula (Graça et al. 2002). While different shredder assemblages may conceivably differ in their susceptibility to altered riparian vegetation (Dangles et al. 2002), the absence of a stream functional response in the Pennine streams may be better explained by the relatively early stage of the knotweed invasion and hence its minor contribution to leaf standing crops. Alternatively, if evenness among leaf decomposing categories in leaf standing crops in autumn is important for the dynamics of shredder populations, as argued by Cummins et al. (1989), it is possible that the scarcity of slow-decomposing leaves in the Pyrenean streams prior to knotweed invasion had a limiting influence 
Fig. 5. Shredder biomass in English oak (Quercus robur) (circles) and Japanese knotweed (Fallopia japonica) (triangles) leaf bags exposed in a reference (open symbols) and an invaded (shaded symbols) stream site in The Pennines $(a)$ and the Pyrenees $(b)$. Mean value and regression line (solid lines, oak; dashed lines, knotweed; thin lines, reference sites; thick lines, invaded sites) through the origin are represented.

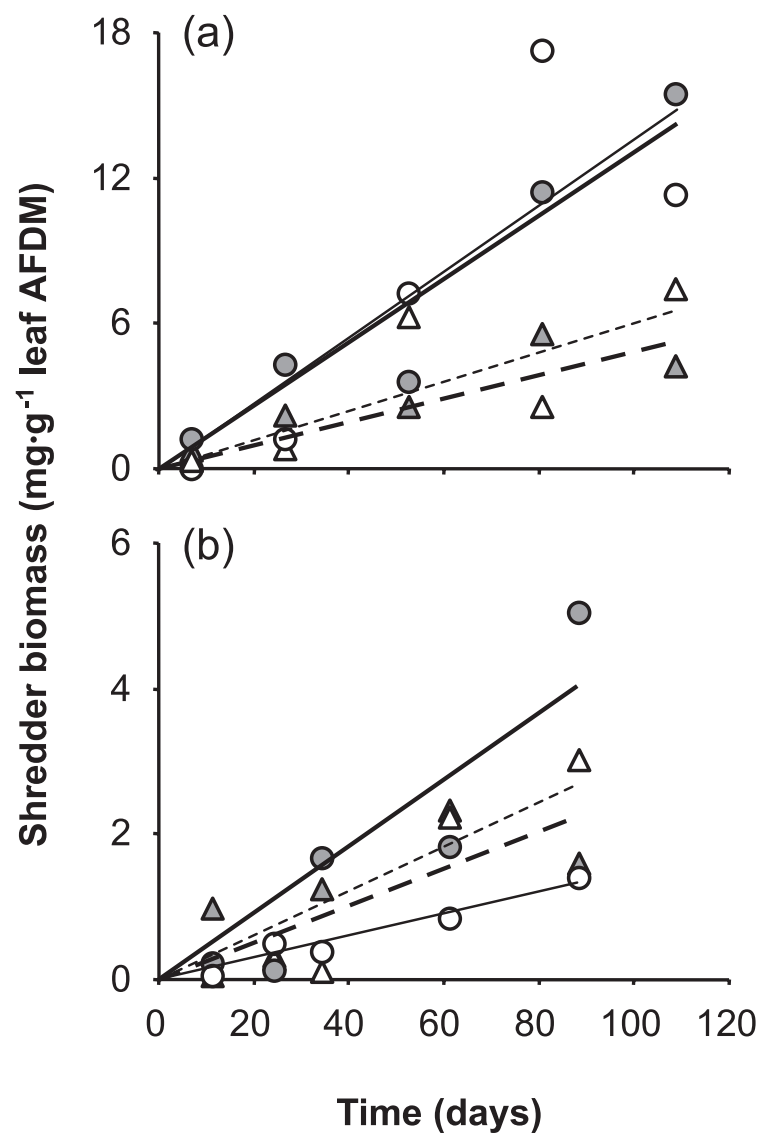

on the production of large shredders. This was not the case in The Pennines, because naturally occurring, slowdecomposing leaves were much more abundant and, hence, probably not limiting.

In this study, the most obvious consequence of Japanese knotweed invasion was the altered species composition of instream leaf standing crops during autumn, resulting in a reduction in average food quality available to aquatic consumers. This negative effect may be exacerbated by the high above-ground productivity of knotweed (Beerling et al. 1994), even though the decrease in food quality may partly be balanced by increased food quantity (Wallace et al. 1997). We feel that a dramatic enhancement of leaf input rate to the two invaded stream sites is unlikely, because either knotweed contributed a small proportion of leaf standing crop (in The Pennines) or it balanced the reduction of native hazel, which naturally contributes greatly to stream leaf input (in the Pyrenees). Whether food quality can compensate for quantity for aquatic consumers remains, however, a critical issue for understanding the consequence of changed riparian vegetation on stream invertebrates (Stout et al. 1993; Lecerf et al. 2005). Other possible consequences of knotweed invasion into riparian zones dominated by herba- ceous and shrubby vegetation include the reduction of light available for primary producers because of the dense knotweed canopy and modification of benthic habitats owing to the loss of submerged root systems (e.g., Kennedy and Hobbie 2004).

To conclude, our study indicates that Japanese knotweed can alter the structure and dynamics of stream detritus food webs. Notably, knotweed leaf litter per se has the potential to strongly affect the assemblages and reduce spore production of aquatic hyphomycetes on leaves, which may have a cascading effect on higher consumers relying on stream fungi (Bärlocher 1992; Lecerf et al. 2005). However, knotweed invasion has unpredictable consequences on major ecosystem processes such as leaf breakdown as a result of either long-term adaptive response of stream biota to knotweed litter or a context-dependent effect of invasion determined by the existing structure and composition of the riparian vegetation and the realized extent of knotweed in the invaded community. Accordingly, we can predict that riparian invasion by exotic plants would have limited effects on streams if $(i)$ plant invaders do not overwhelm the existing riparian vegetation and (ii) the long-term adjustment process of stream ecosystems to changed leaf litter inputs has not been not impaired by any other kinds of disturbance.

\section{Acknowledgements}

This research was supported by the European Commission through the Framework 5 programme (Rivfunction: contract EVK1-CT-2001-00088) and travel grants from the BritishFrench cooperation programme ALLIANCE (ref. 07717ZD), administrated by the British Council and the EGIDE association (French agency for international mobility). We thank Sophie Manzi, Didier Lambrigot, and Boris Bracht for their technical assistance in France and Helen Cariss for the selection of sites in UK. Anne-Marie Planty-Tabacchi and Eric Tabacchi provided helpful advices during the experiment, and two anonymous reviewers improved the manuscript.

\section{References}

Anderson, M.J. 2004. CAP: canonical analysis of principal coordinates [online]. Available from www.stat.auckland.ac.nz/ mja/prog/ CAP_UserNotes.pdf [accessed March 2007].

Anderson, M.J., and Willis, T.J. 2003. Canonical analysis of principal coordinates: a useful method of constrained ordination for ecology. Ecology, 84: 511-525.

APHA. 1998. Standard methods for the examination of water and wastewater. 20th ed. American Public Health Association, Washington, D.C.

Bärlocher, F. 1992. The ecology of aquatic hyphomycetes. Springer-Verlag, Berlin Heidelberg, New York.

Bärlocher, F., and Graça, M.A.S. 2002. Exotic riparian vegetation lowers fungal diversity but not leaf decomposition in Portuguese streams. Freshw. Biol. 47: 1123-1136.

Beerling, D.J., Bailey, J.P., and Conolly, A.P. 1994. Fallopia japonica (Houtt.) Ronse Decraene. J. Ecol. 82: 959-979.

Belnap, J., Phillips, S.L., Sherrod, S.K., and Moldenke, A. 2005. Soil biota can change after exotic plant invasion: does this affect ecosystem processes? Ecology, 86: 3007-3017. 
Child, W., and Wade, M. 2000. The Japanese knotweed manual, the management and control of an invasive weed. Packard Publishing Limited, Chichester, UK.

Cummins, K.W., Wilzbach, M.A., Gates, D.M., Perry, J.B., and Taliaferro, W.B. 1989. Shredders and riparian vegetation. Bioscience, 39: 24-30.

Dangles, O. 2002. Functional plasticity of benthic macroinvertebrates: implication for trophic dynamics in acid streams. Can. J. Fish. Aquat. Sci. 59: 1563-1573.

Dangles, O., Jonsson, M., and Malmqvist, B. 2002. The importance of detritivore species diversity for maintaining stream ecosystem functioning following the invasion of a riparian plant. Biol. Invasions, 4: 441-446.

Dufrêne, M., and Legendre, P. 1997. Species assemblages and indicator species: the need for a flexible asymmetrical approach. Ecol. Monogr. 67: 345-366.

Eggert, S.L., and Wallace, J.B. 2003. Reduced detrital resources limit Pycnopsyche gentilis (Trichoptera: Limnephilidae) production and growth. J. North Am. Benthol. Soc. 22: 388-400.

Ferreira, V., Elosegi, A., Gulis, V., Pozo, J., and Graça, M.A.S. 2006. Eucalyptus plantations affect fungal communities associated with leaf-litter decomposition in Iberian streams. Arch. Hydrobiol. 166: 467-490.

Flindt, M.R., and Lillebø, A.I. 2005. Determination of total nitrogen and phosphorus in leaf litter. In Methods to study litter decomposition: a practical guide. Edited by M.A.S. Graça, F. Bärlocher, and M.O. Gessner. Springer-Verlag, Dordrecht. pp. 45-50.

Friberg, N. 1997. Benthic invertebrate communities in six Danish forest streams: impact of forest type on structure and function. Ecography, 20: 19-28.

Friberg, N., and Jacobson, D. 1999. Variation in growth of the detritivore-shredder Sericostoma personatum (Trichoptera). Freshw. Biol. 42: 625-635.

Gessner, M.O. 2005a. Proximate lignin and cellulose. In Methods to study litter decomposition: a practical guide. Edited by M.A.S. Graça, F. Bärlocher, and M.O. Gessner. Springer-Verlag, Dordrecht. pp. 103-108.

Gessner, M.O. 2005b. Ergosterol as a measure of fungal biomass. In Methods to study litter decomposition: a practical guide. Edited by M.A.S. Graça, F. Bärlocher, and M.O. Gessner. Springer-Verlag, Dordrecht. pp. 171-176.

Gessner, M.O., and Chauvet, E. 1994. Importance of stream microfungi in controlling breakdown rates of leaf litter. Ecology, 75: $1807-1817$.

Gessner, M.O., Chauvet, E., and Dobson, M. 1999. A perspective on leaf litter breakdown in streams. Oikos, 85: 377-384.

Gotelli, N.J., and Colwell, R.K. 2001. Quantifying biodiversity: procedures and pitfalls in the measurement and comparison of species richness. Ecol. Lett. 4: 379-391.

Gotelli, N.J., and Entsminger, G.L. 2006. EcoSim, null model software for ecologists. Version 7 [online]. Available from www.garyentsminger.com/ecosim/index.htm [updated 5 January 2006]. Acquired Intelligence, Inc. \& Kesey-Bear, Jericho, Vt.

Graça, M.A.S. 2001. The role of invertebrate on leaf litter decomposition in streams - a review. Int. Rev. Hydrobiol. 86: 383-393.

Graça, M.A.S., Cressa, C., Gessner, M.O., Feio, M.J., Callies, K.A., and Barrios, C. 2001. Food quality, feeding preferences, survival and growth of shredders from temperate and tropical streams. Freshw. Biol. 46: 947-957.

Graça, M.A.S., Pozo, J., Canhoto, C., and Elosegui, A. 2002. Effects of Eucalyptus plantations on detritus, decomposers and detritivores in streams. The Scientific World Journal, 2: 1173-1185.
Gulis, V. 2001. Are there any preferences in aquatic hyphomycetes? Mycol. Res. 105: 1088-1093.

Hoffmeister, T.S., Vet, L.E.M., Biere, A., Holsinger, K., and Filser, J. 2005. Ecological and evolutionary consequences of biological invasion and habitat fragmentation. Ecosystems, 8: 257-667.

Jonsson, M., Dangles, O., Malmqvist, B., and Guérold, F. 2002. Simulating species loss following perturbation: assessing the effects on process rates. Proc. R. Soc. Lond. B Biol. Sci. 269: 1047-1052.

Kennedy, T.A., and Hobbie, S.E. 2004. Saltcedar (Tamarix ramosissima) invasion alters organic matter dynamics in a desert stream. Freshw. Biol. 49: 65-76.

Laitung, B., and Chauvet, E. 2005. Vegetation diversity increases species richness of leaf-decaying fungal communities in woodland streams. Arch. Hydrobiol. 164: 217-235.

Lecerf, A., Dobson, M., Dang, C.K., and Chauvet, E. 2005. Riparian plant species loss alters trophic dynamics in detritus-based stream ecosystems. Oecologia, 146: 432-442.

Lecerf, A., Risnoveanu, G., Popescu, C., Gessner, M.O., and Chauvet, E. 2007. Decomposition of diverse litter mixtures in streams. Ecology, 88: 201-209.

Legendre, P., and Gallagher, E.D. 2001. Ecologically meaningful transformations for ordination of species data. Oecologia, 129: 271-280.

LeRoy, C.J., Whitham, T.G., Keim, P., and Marks, J. 2006. Plant genes link forests and streams. Ecology, 87: 255-261.

Maerz, J.C., Blossey, B., and Nuzzo, V. 2005. Green frogs show reduced foraging success in habitats invaded by Japanese knotweed. Biodivers. Conserv. 14: 2901-2911.

Naiman, R.J., Décamps, H., and McLain, N. 2005. Riparia: ecology, conservation, and management of streamside communities. Elsevier Academic Press, Burlington, Mass.

Nikolcheva, L.G., and Bärlocher, F. 2005. Seasonal and substrate preferences of fungi colonizing leaves in streams: traditional versus molecular evidence. Environ. Microbiol. 7: 270-280.

Planty-Tabacchi, A.M., Tabacchi, E., Naiman, R.J., Deferrari, C., and Decamps, H. 1996. Invasibility of species-rich communities in riparian zones. Conserv. Biol. 10: 598-607.

Pyšek, P., and Prach, K. 1993. Plant invasions and the role of riparian habitats: a comparison of four species alien to central Europe. J. Biogeogr. 20: 413-420.

Richardson, J.S., Shaughnessy, C.R., and Harrison, P.G. 2004. Litter breakdown and invertebrate association with three types of leaves in a temperate rainforest stream. Arch. Hydrobiol. 159: 309-325.

StatSoft, Inc. 2001. Electronic statistics textbook [online]. Available from www.statsoft.com/textbook/stathome.html [accessed March 2007].

Stout, B.M., Benfield, E.F., and Webster, J.R. 1993. Effects of a forest disturbance on shredder production in southern Appalachian headwater streams. Freshw. Biol. 29: 59-69.

Thompson, R.M., and Townsend, C.R. 2003. Impacts on stream food webs of native and exotic forest: intercontinental comparison. Ecology, 84: 145-161.

Tickner, D.P., Angold, P.G., Gurnell, A.M., and Mountford, J.O. 2001. Riparian plant invasions: hydrogeomorphological control and ecological impacts. Progress in Physical Geography, 25: 22 52.

Wallace, J.B., Eggert, S.L., Meyer, J.L., and Webster, J.R. 1997. Multiple trophic levels of a forest stream linked to terrestrial inputs. Science (Washington, D.C.), 277: 102-104.

Webster, J.R., and Benfield, E.F. 1986. Vascular plant breakdown in freshwater ecosystems. Annu. Rev. Ecol. Syst. 17: 567-594. 
Weston, L.A., Barney, J.N., and DiTommaso, A. 2005. A review of the biology and ecology of three invasion perennials in New York State: Japanese knotweed (Polygonum cuspidatum), mugwort (Artemisia vulgaris) and pale swallow-wort (Vincetoxicum rossicum). Plant Soil, 277: 53-69.
Whiles, M.R., and Wallace, J.B. 1997. Leaf litter decomposition and macroinvertebrate communities in headwater streams draining pine and hardwood catchments. Hydrobiologia, 353: 107-119.

\section{Appendix A}

Table A1. Indicator fungal species and invertebrate taxa characterizing site types and leaf species in The Pennines and the Pyrenees.

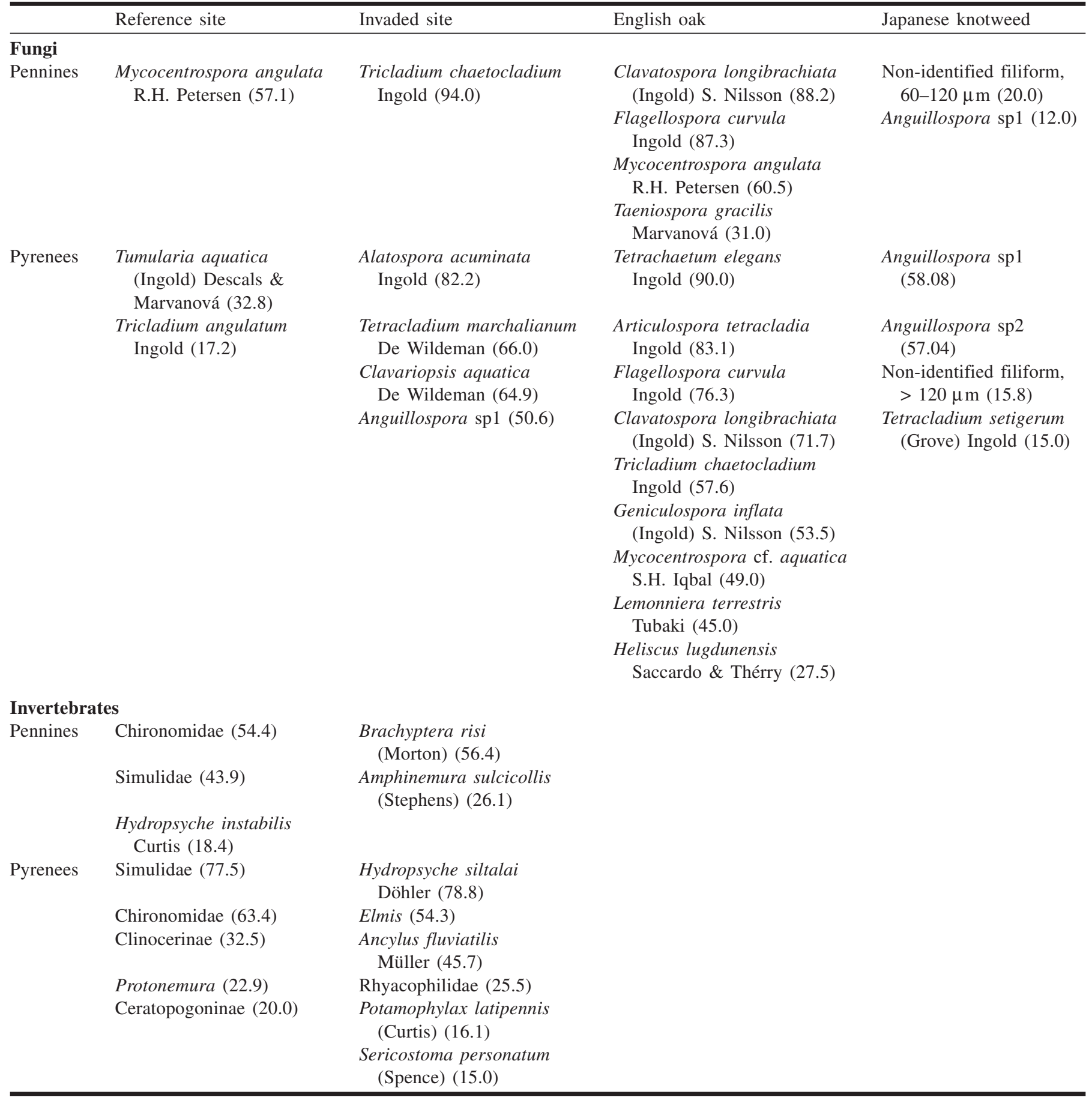

Note: Only taxa for which indicator value (given in parentheses) is significant at $p<0.05$ according to the two randomized tests are shown (see M. Dufrêne and P. Legendre. 1997. Ecol. Monogr. 67: 345-366). 